\title{
Pemanfaatan Awig-Awig dan Perarem dalam Pengelolaan Keuangan Desa Adat
}

\author{
Ni Made Ambar Diantari ${ }^{1}$ \\ Fakultas Ekonomi dan Bisnis \\ Universitas Udayana, Indonesia \\ Email: ambar.diantari@gmail.com
}

\author{
Ni Gusti Putu Wirawati ${ }^{2}$ \\ Fakultas Ekonomi dan Bisnis \\ Universitas Udayana, Indonesia
}

\begin{abstract}
ABSTRAK
Perkembangan akuntansi saat ini banyak diaplikasikan oleh organisasi sosial di masyarakat. Akuntabilitas diperlukan karena dipandang tidak hanya sebatas pertanggungjawaban dan petunjuk bagi organinasi, namun memiliki fungsi lain dalam bidang interaksi antara etika, sosial, dan lingkungan akuntansi. Desa adat di Bali melakukan fungsi akuntansi dengan berpedoman pada awig-awig dan perarem yang disepakati oleh seluruh prajuru adat dan krama adat. Penelitian ini dilakukan untuk mengetahui bagaimana desa adat dapat menjalankan fungsi akuntansinya dengan berpedoman pada awig-awig dan perarem. Penelitian ini melakukan observasi, wawancara, dan dokumentasi dala mengumpulkan data. Untuk memastikan data yang disajikan valid, penelitian ini menggunakan teknik triangulasi. Hasil penelitian ini menunjukkan bahwa pemanfaatan awig-awig dan perarem dalam pengelolaan keuangan desa adat dilakukan oleh prajuru Desa Adat Awan yang didasari atas pemahaman dan pengetahuan mengenai sumber dana, mobilisasi dan alokasi dana, serta pertanggungjawaban keuangan berlandaskan Tri Hita Karana.
\end{abstract}

Kata Kunci : $\quad$ Desa Adat; Akuntabilitas;Awig-Awig;Perarem.

\section{Utilization Of Awig-Awig And Perarem In The Financial Management Of Customary Village}

\begin{abstract}
The development of accounting is widely applied by social organizations in society. Accountability is seen as not only limited to accountability and guidance for the organization, but has other functions of interaction between the ethical, social, and accounting environment. Traditional villages in Bali carry out accounting functions based on awig-awig and perarem as agreed by all customary officers and customary manners. This research was conducted to find out how indigenous villages can carry out their accounting functions based on awig-awig and perarem. This study using the methods of observation, interviews, and documentation. To ensure the data presented are valid, this study uses triangulation techniques. The results indicate that the use of awig-awig and perarem in the management finances is carried out by the Adat Awan village commander based on understanding and knowledge of funding sources, mobilization and allocation of funds, and financial accountability based on Tri Hita Karana.
\end{abstract}

Keywords: Customary Village; Accountability; Awig-Awig;

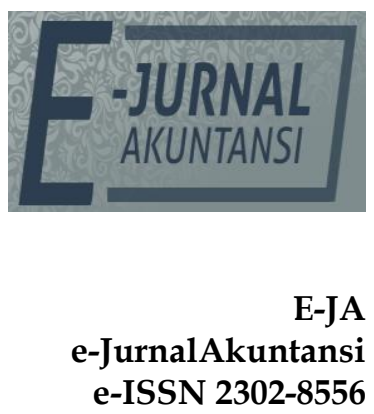

Vol. 29 No. 3

Denpasar, Desember

2019

Hal.1106-1116

Artikel masuk: 4 September 2019

Tanggal diterima: 17 Desember 2019 


\section{PENDAHULUAN}

Organisasi pada era reformasi saat ini digambarkan oleh adanya akuntabilitas yang dituntut dalam pelaksanaan organisasi tersenut (Wirajaya, 2014). Konflik yang terjadi pada organisasi sektor publik nirlaba Lembaga Swadaya Masyarakat (LSM) sebagian besar dilandasi oleh dominannya kepentingan individu maupun kelompok dalam organisasi tersebut (Ardhian, 2011). Akuntabilitas yang menggunakan akuntansi sebagai pedomannya pada dasarnya mempunyai banyak makna, tergantung pada bagaimana akuntansi bagaimana akuntansi tersebut diterapkan dan dimana akuntansi tersebut dipraktikkan (Hopwood, 1987). Perkembangan akuntansi tidak hanya diterapkan oleh organisasi bisnis, namun saat ini juga banyak diaplikasikan pada organisasi non bisnis dan di berbagai sistem sosial dalam masyarakat. Praktik akuntansi di berbagai sistem sosial dalam masyarakat dipandang sebagai suatu bentuk pertanggungjawaban (Ives et al., 2004:454).

Pada hal ini, akuntabilitas memiliki tiga dimensi yang pertama, compliance yang menyiratkan akan kepatuhan pada ketentuan, norma, dan peraturan yang ada. Kedua, transparancy menyiratkan penerapan pemberian laporan oleh agen kepada prinsipal yang harus dilakukan secara terbuka sehingga terjadi kesamaan informasi antara agen dengan prinsipal. Ketiga, responsiveness yang menyiratkan kemauan dan kemampuan agen untuk merespons harapan dan hak prinsipal (Visser et al., 2010:5)

Tetlock \& Kim (1987) mendefinisikan akuntabilitas sebagai bentuk dorongan psikologis yang membuat seseorang berusaha mempertanggungjawabkan semua tindakan dan keputusan yang diambil kepada lingkungannya. Menurut Standbury (2003) akuntabilitas dimaknai sebagai suatu kewajiban untuk mempertanggungjawabkan dan menggambarkan hasil pelaksanaan misi organisasi dalam menuju sasaran yang telah ditetapkan melalui media akuntansi yang dilaksanakan secara periodik. Pada sisi lain, menurut Patton (1992) menyatakan bahwa akuntabilitas sesungguhnya memiliki konsep tidak hanya mengenai pertanggungjawaban finansial secara formal saja, namun lebih dari itu dimana kemampuan meningkatkan tanggung jawab kepada masyarakat, pemerintah, dan kepatuhan pada peraturan.

Setiap daerah yang ada di wilayah Indonesia ditopang oleh adanya desa yang ikut andil dalam menjaga kestabilan pelaksanaan pemerintahan. Desa memiliki pemerintahan tersendiri dimana pemerintahan desa menyelenggarakan urusan pemerintahan dan kepentingan masyarakat setempat. Dalam masyarakat Bali, terdapat dua bentuk pemerintahan desa yang masing-masing memiliki fungsi, tugas, dan struktur organisasi yang berbeda. Kedua bentuk tersebut yaitu Desa Dinas dan Desa Adat atau Desa Pakraman.

Pemerintahan desa adat di Provinsi Bali masih dapat mempertahankan eksistensinya sampai saat ini dan mampu bersanding dengan desa dinas bentukan Undang-Undang Pemerintahan Pusat. Desa adat memiliki sebuah aturan yang dibuat oleh desa adat dan/atau banjar adat yang berlaku bagi krama desa adat, krama tamiu, dan tamiu dalam bentuk awig-awig dan perarem desa adat. Awig-awig adalah hukum organisasi tradisional di Bali, yang dibuat secara musyawarah mufakat oleh seluruh masyarakat dan digunakan sebagai pedoman bertingkah laku dari anggota organisasi yang bersangkutan. Perarem merupakan 
suatu kesepakatan bersama yang diputuskan dalam suatu pertemuan atau rapat mengenai sesuatu.

Desa Adat Awan adalah sebuah desa yang terletak di Kecamatan Kintamani, Kabupaten Bangli. Desa Adat Awanmerupakan organisasi sosial yang dalam pertumbuhan dan perkembangannya menjadikanawig-awig dan perarem sebagai pedoman untuk bertindak dan berperilaku sehari-hari serta budaya gotong royong disetiap aktivitas masyarakatnya. Mengingat pentingnya desa adat sebagai organisasi sosial dalam kehidupan sosial umat di Bali yang memiliki sistem dan pedoman organisasi yang berbeda dengan desa dinas.

Keunikan organisasi desa adat, terdapat beberapa aspek penting dalam akuntabilitas struktur keuangan organisasi desa adat yakni pertama, implementasi akuntabilitas keuangan dalam organisasi desa adat sebagai organisasi non profit belum banyak dieksplorasi dalam berbagai riset, sehingga menjadi sangat penting untuk mengetahui secara mendalam praktik pengelolaan keuangan pada organisasi desa adat. Kedua, mengingat secara konseptual akuntabilitas keuangan bukan hanya sekedar perhitungan konvensional namun lebih pada keterlibatan interaksi nilai-nilai sosial budaya lokal dalam pengelolaan keuangan organisasi desa adat menjadi hal yang menarik dalam penelitian ini.

Desa Adat Awan menggunakan awig-awig dan perarem sebagai pedoman dalam pengelolaan keuangan desa adat. Tujuan dari penelitian ini adalah untuk mengetahui, mengidentifikasi, mengdeskripsikan, menganalisis, dan menginterprestasikan penerapan awig-awig dalam pengelolaan keuangan desa adat di Desa Adat Awan, Kecamatan Kintamani, Kabupaten Bangli dan untuk mengetahui, mengidentifikasi, mengdeskripsikan, menganalisis, dan menginterprestasikan penerapan perarem dalam pengelolaan keuangan desa adat di Desa Adat Awan, Kecamatan Kintamani, Kabupaten Bangli.

\section{METODE PENELITIAN}

Desain yang digunakan dalam penelitian ini adalah pendekatan kualitatif yang menggunakan studi paradigma interpretif melalui metode etnometodologi. Penelitian kualitatif adalah penelitian dengan menguraikan, menerjemahkan, dan menjelaskan pendapat responden apa adanya sesuai dengan peryataan penelitian yang kemudian diinterprestasikan sehingga mendapat hasil penelitian (Rahyuda, 2016). Penelitian paradigma interpretif tersebut adalah penelitan yang memiliki usaha untuk menjelaskan tindakan dan makna yang mana apakah memiliki hubungan. Metode etnometodologi digunakan dengan maksud untuk mendalami unsur sosial budaya dalam penelitian ini yang berfokus pada pengkajian akuntabilitas keuangan organisasi pemerintahan desa adat dengan memanfaatkan awig-awig dan perarem sebagai pedoman.

Metode pengumpulan data yang digunakan untuk dapat menjawab permasalahan yang ada di dalam penelitian ini terdiri atas pengamatan (observation), wawancara (interview), dan dokumentasi (documentation) seperti yang disebutkan (Goulding, 1998). Objek penelitian ini adalah Pemanfaatan Awig-Awig dan Perarem Desa Adat Awan Kecamatan Kintamani Kabupaten Bangli. Validasi dan keabsahan data dalam penelitian kualitatif dapat dilakukan melalui metode triangulasi. Penelitian sebagai instrumen kunci dalam 
memperoleh data dilapangan melalui proses wawancara dan rekaman. Selain itu, instrumen lain yang dapat digunakan untuk mendukung penelitian antara lain alat perekam, kamera, dan alat tulis.Bentuk data dari dokumentasi ini dalam bentuk tulisan atau bentuk gambar yang menambah bahasa dan kosakata dalam menginterprestasikan hasil observsi dan wawancara (Creswell, 1994).

\section{HASIL DAN PEMBAHASAN}

Dalam menjalankan pemerintahannya, desa adat memerlukan anggaran untuk membiayai kegiatan operasional. Untuk memastikan anggaran telah dikelola dengan baik adapun aspek yang harus diperhatikan yaitu: tanggung jawab pengelolaan keuangan, metode mobilisasi dana, alokasi pemanfaatan dana untuk kegiatan desa adat, dan pertanggungjawaban atau akuntabilitas penggunaan dana yang telah dikeluarkan.

Desa Adat Awan merupakan organisasi sosial yang dalam pelaksanaan pemerintahannya menggunakan awig-awig dan perarem desa adat sebagai acuan dalam bertindak. Awig-awig dan perarem desa adat berisikan informasi dimulai dari data aset yang dimiliki desa adat, sumber dana organisasi desa adat, mobilisasi dan alokasi dana organisasi desa adat, dan pertanggungjawaban yang dilakukan oleh desa adat, dimana seluruh aktivitas ini diatur agar sesuai dengan prinsip ideologi Tri Hita Karana.

Desa Adat Awan mempunyai aturan (tertulis maupun tidak tertulis) yang berlaku bagi semua masyarakatnya., bentuk aturan ini disebut dengan awigawig. Awig-awig adalah peraturan atau pedoman yang dipergunakan oleh prajuru desa adat dalam menjalankan kegiatan-kegiatan di desa adat. Desa adat sebagai salah satu bentuk organisasi tradisional, dalam segala hal yang masih berpegangan teguh dengan kebersamaan antar krama desa adat. Adapun hal yang tertera dalam awig-awig desa adat adalah informasi aset yang dimiliki desa adat, sumber dana desa adat, sumber dana dari penerapan kearifan lokal, dan pertanggungjawaban Desa Adat Awan. Awig-awig yang digunakan Desa Adat Awan mulai berlaku disahkan pada tanggal 19 April tahun 1994 dan masih berlaku sampai saat ini.

Dalam awig-awig telah dipaparkan apa saja aset atau padruwen yang dimiliki oleh desa adat baik itu aset berupa tanah, bangunan, dan juga dalam bentuk kesenian yang tertera dalam Palet 5 Pawos 20 Bantang Awig-Awig Desa Adat Awan.

Tabel 1. Daftar Aset Desa Adat Awan

\begin{tabular}{lll}
\hline & \multicolumn{2}{c}{ Daftar Aset } \\
\hline Pura Desa & Pura Subak Cempaka Kembar & Setra Pingit \\
Pura Puseh & Pura Subak Jineng Batu & Setra Bantes \\
Pura Dalem & Pura Subak Ukir Kawi & Gong Barungan \\
Pura Prajapati & Pura Subak Merta Sari & Tari Baris Teruna \\
Pura Ulun Suwi & Pura Subak Pemujaan & Tari Rejang Deha \\
Pura Gunung Lebah & Pura Pahuripan & Pesantian \\
Pura Mpu Jangga & Tugu Pemangkalan Desa & Tanah Pecatu \\
Pura Beji & Tanah Laba Pura & LPD \\
Pura Padma Sana & Setra Alit & \\
\hline
\end{tabular}

Sumber : Data Penelitian, 2019 
Berdasarkan Bantang Awig-Awig Desa Adat Awan Palet 5 Pawos 22 dan Perda Provinsi Bali No 4 Tahun 2019, sumber pendapatan desa adat tersebut berasal dari : pendapatan dari Pelaba Pura, pendapatan dari urunan Krama Desa Adat, pendapatan dari Pemerintah, pendapatan lainnya yang sah, dan hibah dan sumbangan (dana punia) pihak ketiga yang tidak mengikat (Perda Provinsi Bali No. 4/2019, BAB X, Pasal 65).

Sumber pendapatan yang tersurat dalam Awig-Awig Desa Adat Awan dan Perda Provinsi Bali No 4 Tahun 2019, secara langsung memberikan kewenangan dan kepercayaan bagi organisasi Desa Adat Awan untuk mengelola sumbersumber penghasilan yang dimilikinya. Hasil dari pengelolaan ini sepenuhnya digunakan untuk kepentingan masyarakat dan desa adat itu sendiri seperti pembangunan fasilitas sosial dan umum, peningkatkan kesejahteraan masyarakat, menjaga kekayaan tradisi adat dan budaya, serta menjaga kelestarian alam dan lingkungan sekitarnya dengan tetap berpedoman pada ideologi THK.

Sumber dana organisasi desa adat yang diatur lebih lanjut dalam awig-awig adalah sumber pendapatan lain yang dianggap sah, dalam hal ini adalah sumber pendapatan dari penerapan kearifan lokal di Desa Adat Awan. Desa adat dalam menjalankan organisasinya juga memperoleh dana dari penerapan kearifan lokal. Kearifan lokal merukapan segala hal yang berbentuk pengetahuan, keyakinan, pemahaman, dan adat kebiasaan atau etika yang menuntun perilaku manusia dalam kehidupan di dalam komunitas ekologis(Keraf, 2010).

Adapun bentuk pungutan dana yang dilakukan desa adat adalah masyarakat desa adat lain yang ingin melaksanakan penguburan mayat di Setra Desa Adat Awan wajib membayar Penanjung Batu 250 keping uang bolong, masyarakat Desa adat Awan yang akan melangsungkan pernikahan wajib membayar Perebu Kulak di Pura Bale Agung yang berisikian sesari sebanyak 225 keping uang bolong, serta menghaturkan Kelaci yang berisi sesari sebanyak 60 ribu rupiah dan 225 keping uang bolong, dan wajib menghaturkan $20 \mathrm{~kg}$ daging babi yang dapat diuangkan sesuai dengan harga pasaran daging saat itu, masyarakat yang akan melangsungkan pernikahan yang diadakan bersamaan dengan pembangunan di pura yang ada di lingkungan desa adat wajib membayar tambahan yang disebut Pegat Tambat yaitu $20 \mathrm{~kg}$ daging babi yang juga dapat diuangkan sesuai dengan harga pasaran daging saat itu, masyarakat yang akan melangsungkan pernikahan namun mengalami kehamilan sebelum pernikahan tersebut dilaksanakan wajib membayar denda Sipatan yaitu $20 \mathrm{~kg}$ daging babi dan dapat diuangkan sesuai dengan harga pasaran daging saat itu.

Organisasi Desa Adat Awan mempercayai bahwa apa yang dimiliki oleh desa adat adalah pemberian dari Tuhan Yang maha Esa. Adanya pemahaman tersebut menjadikan organisasi ini merasa memiliki kewajiban untuk menghaturkannya kembali dalam bentuk pelaksanaan kegiatan upacara keagamaan sebagai bentuk pertanggungjawaban atas anugerah yang diberkahi kepada desa adat. Pertanggungjawaban yang diatur dalam Awig-Awig Desa Adat Awan ini merupakan bentuk pertanggungjawaban yang berlandaskan dengan ideologi THK di bidang Parahyangan dan Pawongan.

Bentuk pelaksanaan pertanggungjawaban desa adat yang berhubangan dengan ideologi THK dalam aspek parahyangan adalah menjalankan upacara 
keagaaman sesuai dengan hari piodalan masing-masing khayangan, seperti Pura Desa atau Pura Bale Agung dilaksakanan piodalan setiap Tumpek Landep, Anggara Kasih Julungwangi, Budha Kliwon Matal, Budha Wage Kelawu, Sukra Umanis Kelawu bersamaan dengan Anggara Kasih dan Purnama, Pura Puseh pada saat Purnama Kedasa, Pura dalem dan Pura Prajapati saat Anggara Kasih dukut, Pura Ulun Suwi saat Purnama Kapat, Pura Gunung Lebah saat Purnama Kapitu, Pura Mpu Jangga saat Saniscara Umanis Watugunung, dan Pura Beji saat Purnama Kasa;

Pelaksanaan upacara tersebut sebagai bentuk pertanggungjawaban dan juga wujud bakti Desa Adat Awan kepada Tuhan Yang Maha Esa selaku pencipta. Pertanggungjawaban ini juga untuk menjaga hubungan harmonis antara Desa Adat Awan dengan pencipta-Nya.

Filosofi pawongan yaitu hubungan harmonis antara manusia dan sesamanya yang dalam hal ini desa adat diharapkan dapat bertanggungjawab terhadap masyarakatnya guna menjaga hubungan harmonis yang telah tercipta. Pertanggungjawaban desa adat kepada masyarakat yaitu pelaporan keuangan.Tujuan utama dari semua proses akuntansi adalah pelaporan keuangan, dimana pelaporan keuangan adalah sebuah alur atau proses yang menyajikan informasi akuntansi dengan harapan dapat mencapai tujuan ekonomi dan sosial.

Pelaporan keuangan tersebutlangsung disampaikan pada paruman pertanggungjawaban oleh prajuru Desa Adat Awan yang terangkum dalam sebuah laporan keuangan yang sederhana. Media akuntabilitas dalam bentuk laporan keuangan memiliki fungsi yang sangat strategis dalam menjelaskan kinerja dan fenomena akuntansi dalam organisasi Desa Adat Awan. Pertanggungjawaban prajuru desa dalam pengelolaan aset dan dana desa adat, serta mempunyai peran dalam menentukan perjalanan organisasi dilakukan dalam bentuk laporan keuangan. Informasi yang tersurat dalam laporan keuangan umumnya akan digunakan oleh pihak yang berkepentingan untuk menilai kinerja organisasi. Penyusunan laporan keuangannya Desa Adat Awan menggunakan pencatatan berbasis kas sebagai metodenya dengan menerapkan konsep pengukuran, prinsip objektivitas, dan ketepatan waktu dalam penyajian sehingga laporan yang tersaji memberikan informasi yang relevan dan akuntabel.

Pertanggungjawaban yang disampaikan oleh organisasi Desa Adat Awan selain memperhatikan objektivitas tetapi juga sangat memperhatikan relevansinya. Informasi yang relevan merupakan salah satu hal yang terpenting dalam pengambilan keputusan, hal itu yang menyebabkan organisasi tersebut menyampaikan pertanggungjawaban secara tepat waktu. Organisasi Desa Adat Awan secara konsisten melakukan paruman (rapat) setiap bulan dengan menggunakan hari Anggara Kasih sebagai patokan dalam pelaksanaanya, dimana dalam paruman ini berbagai hal yang dirasa perlu disampaikan oleh prajuru desa kepada masyarakat desa akan disampaikan. Dalam awig-awig disampaikan bahwa paruman ini dilakukan tanpa arahan sebelumnya, dengan ini diperlukan kesadaran prajuru dan krama masing-masing.

Desa Adat Awan dalam menjalankan tugasnya mengadakan paruman rutin sebulan sekali sebagai sarana untuk mebahas kondisi terkini dari desa adat. 
Apabila sewaktu-waktu terdapat masalah yang dihadapi oleh krama desa atau desa adat itu sendiri, biasanya masalah tersebut diutarakan pada saat paruman. Pada kondisi tersebut Bendesa Adat memiliki wewenang memutuskan masalah atau sengketa yang dihadapi oleh masyarakat atau desa adat tersebut berdasarkan musyawarah mufakat dan mengacu kepada ketentuan yang ada di desa adat.

Hasil dari paruman yang rutin dijalankan disebut dengan perarem. Perarem merupakan hasil paruman yang terbentuk karena adanya suatu masalah atau kondisi yang harus diselesaikan yang tidak tertera dalam awig-awig, dimana perarem tersebut diperoleh dari kesepakatan seluruh peserta paruman. Adapun hal yang diatur lebih lanjut dalam perarem yang berkaitan dengan pengelolaan keuangan desa adat adalah sumber dana dari urunan krama Desa Adat Awan, sumber dana dari dana punia, sumber dana dari hasil pengelolaan aset Desa Adat Awan, sumber dana dari LPD Desa Adat Awan, sumber dana dari pemerintah, sumber dana dari penerapan sanksi,mobilisasi dan alokasi sumber dana pada organisasi Desa Adat Awan, dan pertanggungjawaban Desa Adat Awan.

Pendapatan dari urunan krama merupakan iuran yang dipungut secara rutin dari masyarakat Desa Adat Awan. Iuran tersebut muncul sebagai akibat dari adanya rutinitas kegiatan upacara adat keagamaan. Urunan krama desa baru akan ada jika suatu kegiatan yang akan terlaksana dirasa membutuhkan tambahan dana dari krama yang nantinya akan bersifat jangka pendek. Terdapat dua jenis urunan dari krama yang biasa dipungut oleh desa adat. Urunan yang pertama adalah urunan yadnya dimana urunan ini dipungut untuk modal desa adat dalam melakukan upacara keagaaman. Urunan yadnya dibebankan kepada Krama Desa Pengarep, Krama Desa Karang, dan Krama Desa Yadnya dengan jumlah yang sama rata sehingga diperoleh totalan sebesar $50 \%$ dari rancangan anggaran yang akan dikeluarkan.

Urunan yang kedua adalah urunan pembangunan dimana urunan ini dipungut apabila akan diberlangsungkan pembangunan maupun renovasi dari tempat suci yang ada di weweidangan Desa Adat Awan. Urunan ini dibebankan Krama Desa Pengarep dan Krama Desa Karang dengan besaran Krama Desa Pengarep 100\% dan Krama Desa Karang 20\% dengan totalan yang akan dihasilkan sebesar $50 \%$ dari anggaran yang telah dirancang.

Dana punia merupakan sumbangan finansial maupun non finansial secara tulus ikhlas yang dilakukan oleh seseorang pada kegiatan adat maupun keagamaan. Selama ini, masyarakatDesa Adat Awan juga mempercayai bahwa penghasilan yang diperoleh dalam menjalankan aktivitas sehari-hari sangat dipengaruhi oleh kehendak-Nya. Oleh sebab itu masyarakat desa berkeyakinan untuk wajib mempersembahkan kembali dalam bentuk dana punia (yadnya) pada setiap kegiatan upacara adat keagamaan. Jumlah atau nilai material yang disumbangkan bervariasi, tidak ada batasan minimal maupun maksimalnya dan ini merupakan ungkapan rasa syukur masyarakat atas segala anugerah yang telah dilimpahkan oleh-Nya selama ini. Realitas ini menjelaskan bahwa tindakan masyarakat sangat dipengaruhi oleh kepercayaan dan keyakinan yang selama ini menjadi ideologinya.

Terdapat sejumlah 15 ha pelaba pura dalam bentuk lahan yang dikelola oleh Desa Adat Awan. Terkait dengan pengelolaan lahan tersebut organisasi 
Desa Adat Awan mengeluarkan kebijakan sistem nyakap dimana desa adat sebagai pemilik lahan bekerjasama dengan pihak lain yang berkenan untuk mengelola lahan tersebut. Desa Adat dalam hal ini telah menetapkan aturan bahwa penyakap selaku pihak yang mengelola lahan tersebut hanya diperkenankan menggunakan lahan milik desa adat untuk ditanami jeruk. Masyarakat yang diprioritaskan dalam sistem nyakap tanah pelaba pura ini adalah masyarakat Desa Adat Awan yang tidak memiliki tanah pribadi dan dinilai mampu untuk mengelola lahan tersebut.

Desa adat selaku penyedia lahan dan pihak lain berperan membiayai produksi lahan dan bertugas dalam proses pemeliharaan lahan sampai dengan proses panen. Untuk hasil panen jeruk akan dibagi dengan rasio pembagian 1:2, 1 untuk desa adat dan 2 untuk pihak lain selaku penyakap. Dalam pengelolaan lahan tersebut apabila masyarakat selaku penyakap dinilai lalai dalam menjaga tanah aset desa tersebut maka akan diberikan teguran berupa Surat Peringatan sebanyak 3 kali. Desa adat berhak mencabut hak atas pengelolaan tanah tersebut apabila kondisi lahan tidak membaik setelah pemberian teguran final diberikan, dan lahan dapat diambil alih oleh masyarakat yang lain yang dianggap mampu sesuai dengan hasil keputusan paruman.

Hasil dari pemberdayaan aset Desa Adat Awan seluruhnya dikumpulkan pada LPD setempat, yang selanjutnya dimanfaatkan dan dikelola kembali sebagai modal LPD. Hasil pengelolaan LPD sampai dengan saat ini telah memberikan sumbangan yang besar terhadap keuangan organisasi Desa Adat Awan. Pada tahun 2018 jumlah laba yang dihasilkan LPD Desa Adat Awan sebesar Rp 803.042.548. Dari jumlah tersebut 60\% dialokasikan ke cadangan modal LPD, 20\% dialokasikan ke dana pembangunan desa yang pada hal ini dikelola oleh desa adat, 10\% dialokasikan ke jasa produksi, 5\% dialokasikan ke dana pemberdayaan, pengawasan, dan perlindungan LPD, dan $5 \%$ sisanya dialokasikan ke dana sosial.

Pemprov Bali dan Pemda berkomitmen dalam menjaga dan melestarikan warisan budaya Bali yang diwujudkan dengan pemberian bantuan bagi desa adat. Pada tahun 2019 Pemerintah Provinsi Bali mengalokasikan anggaran untuk desa adat sebesar 225 juta dan 10 juta dana pasraman. Bantuan ini disalurkan melalui Bantuan Keuangan Khusus (BKK) kepada Desa Dinas pada APB Desa.

Sanksi merupakan suatu bentuk pemaksaan terhadap masyarakat dalam hal adanya perintah-perintah, kewajiban-kewajiban, atau larangan-larangan yang diatur secara tertulis maupun tidak tertulis yang disepakati seluruh anggota organisasi. Adapun sanksi yang diterapkan Organisasi Desa Adat Awan untuk mengikat tingkah laku masyarakatnya adalah denda bagi siapapun yang berburu di wilayah Desa Adat Awan sebesar $20 \mathrm{~kg}$ daging babi dan denda sebesar 2 ribu rupiah bagi krama yang tidak hadir pada saat paruman dilaksanakan.

Latar belakang diterapkannya sanksi ini adalah semata-mata untuk mengatur tingkah laku masyarakat dan kepatuhan terhadap peraturan yang disepakati dan diterapkan pada desa adat.

Dana yang telah terkumpul dan dimiliki oleh desa adat dari berbagai sumber kemudian dialokasikan untuk kepentingan masyarakat dan pelaksanaan rutinitas kegiatan Desa Adat Awan. Kegiatan rutin yang biasa dilakukan pada 
organisasi ini diantaranya adalah mengadakan upacara keagamaan, melaksanakan pembangunan di segala bidang keagamaan, kebudayaan, dan kemasyarakatan, serta memelihara dan melestarikan seluruh aset desa.

Terdapat 3 jenis kas yang digunakan Desa Adat Awan untuk mempermudah dalam mobilisasi dan alokasi dana yang dimiliki desa adat. Kas yang pertama merupakan kas bagi hasil jeruk atau yang masyarakat Desa Awan sebut dengan kas besar. Kas ini bersumber dari sumber dana pengelolaan aset desa dan khusus diperuntukan untuk pembangunan di bidang keagamaan. Per Oktober 2019 Desa Adat Awan memiliki total 606 juta rupiah kas besar yang akan digunakan untuk meringankan beban masyarakat dalam melakukan urunan pembangunan, sehingga pembangunan di bidang keagamaan akan didanai 50\% dari Dana BKK ataupun dana SHU dari LPD dan 50\% nya menggunakan dana kas besar, dengan hal ini masyarakat tidak lagi dipungut urunan pembangunan selama kas desa adat dinilai masih mampu untuk menutupi kekurangan dana tersebut.

Bentuk kas yang kedua adalah adalah kas yadnya atau yang masyarakat sebut dengan kas umum. Kas ini bersumber dari urunan yadnya, dana punia dan juga sumber lain yang sah. Kas yadnya akan dialokasikan untuk upacara keagamaan, kegiatan sosial, maupun pengeluaran desa adat yang bersifat umum. Per Oktober 2019 kas yadnya yang dimiliki desa adat awan adalah sebesar 53 juta rupiah.

Kas yang ketiga adalah kas pembangunan. Kas ini bersumber dari urunan pembangunan yang dilakukan oleh masyarakat Desa Adat Awan yang kemudian akan digunakan untuk pembangunan dalam bidang keagamaan. Per Oktober 2019 kas pembangunan yang dimiliki Desa Adat Awan berjumlah 5 juta rupiah. Kas pembangunan memiliki dana yang paling kecil karena untuk saat ini masyarakat dibebaskan dari urunan pembangunan karena kas besar dirasa masih cukup untuk membiayai $50 \%$ pengeluaran pembangunan yang sedang terlaksana.

Tahapan akhir dari proses pengelolaan keuangan adalah pertanggungjwaban. Desa adat wajib mempertanggungjawabkan segala proses yang berkaitan dengan pengelolaan keuangan desa adat. Bentuk pertanggungjwaban ini harus juga berlandaskan pada ideologi THK. Adapun pertanggungjawaban yang telah dilaksanakan oleh Desa Adat Awan berdasarkan aspek THK yang berpedoman terhadap perarem yang telah disepakati adalah:

Implementasi pertanggungjawaban dalam bidang palemahan bertujuan untuk menjaga hubungan harmonis antara desa adat dengan lingkungan sekitarnya. Desa Adat Awan dalam hal ini telah melaksanakan kewajibannya dengan menjaga dan merawat lingkungan desa adat yang dapat dilihat dari dilakukannya pembangunan maupun perbaikan terhadap aset yang dimiliki desa adat. Diterapkannya sistem nyakap terhadap pelaba pura juga salah satu bentuk pertanggungjawaban desa adat guna memastikan seluruh aset dapat dirawat dan dikelola dengan baik. 


\section{SIMPULAN}

Berdasarkan hasil analisis dan pembahasan yang telah dipaparkan pada bab sebelumnya, bahwa konsep akuntabilitas yang terkontruksi pada pemerintahan desa adat dengan memanfaatkan awig-awig dan perarem sebagai pedoman dalam pengelolaan keuangan desa adat di Desa Adat Awan, Kecamatan Kintamani, Kabupaten Bangli didapatkan simpulan sebagai berikut sumber dana: Awig-awig memberikan gambaran umum mengenai aset yang dimiliki oleh desa adat, jenis sumber dana desa adat, dan sumber dana dari penerapan kearifan lokal, sedangkan perarem memberikan pedoman mengenai sumber dana yang lebih terperinci yang berasal dariurunan krama, dana punia, pengelolaan aset desa adat, LPD desa adat, pemerintah, dan penerapan sanksi. Mobilisasi dan alokasi dana : Mobilisasi dan alokasi dana yang tersumber dari pemanfaatan awig-awig dan perarem sebagai pedomannya, mempunyai tujuan yang sama yakni digunakan untuk kepentingan pelaksanaan kegiatan desa adat diantaranya menyelenggarakan upacara keagamaan, pembangunan di segala fasilitas umum bidang keagamaan, kebudayaan, dan kemasyarakatan, serta memelihara dan melestarikan seluruh aset desa.Pertanggungjawaban keuangan : Informasi mengenai penerimaan dana dan pengalokasian dana dari awig-awig dan perarem dipertanggungjawabkan dalam forum yang sama setiap bulan dengan menggunakan patokan hari Anggara Kasih sebagai jadwal paruman rutin desa adat. Pertanggungjawaban tersebut dilakukan oleh Prajuru Desa terhadap krama desa sebagai bentuk transparansansi pengelolaan keuangan dan aset desa yang dilakukan.

Berdasarkan hasil pengamatan dan wawancara menunjukkan bahwa masih adanya kekurangan dalam proses pengelolaan keuangan yang tercermin dari kurang informatifnya laporan ataupun catatan keuangan yang dihasilkan oleh Organisasi Desa Adat Awan. Saran yang dapat diberikan dari kekurangan ini adalah perlu adanya pelatihan khusus terhadap Prajuru Desa Adat Awan dalam konteks pencatatan atas laporan keuangan sehingga nantinya dapat disajikan laporan keuangan yang informatif. Di masa sekarang ini sudah sepatutnya organisasi sosial nirlaba tidak hanya berpedoman pada awig-awig dan perarem namun juga harus memahami ilmu akutansi modern agar dapat menghasilkan laporan keuangan yang lebih terstruktur demi mewujudkannya pengelolaan keuangan yang lebih berkualitas.Peneliti juga sadar penelitian ini memiliki keterbatasan dan jauh dari kesempurnaan. Keterbatasan tersebut adalah pada proses penelitian. Penelitian ini adalah suatu bentuk implementasi penerapan awig-awig dan perarem dalam pengelolaan keuangan desa adat. Peneliti menggunakan metode etnometodologi untuk mencapai tujuan penelitian yang diharapkan. Namun, penelitian ini dilakukan dalam waktu yang singkat. Keterbatasan berikutnya adalah kemampuan peneliti dalam mengeksplorasi, menginterprestasikan, dan menuliskan suatu realitas sosial, menunjukkan hasil dari penelitian ini masih jauh dari kata sempurna. Saran yang dapat diberikan dari kekurangan ini adalah diharapkan peneliti selanjutnya dapat lebih detail dalam melakukan wawancara dan observasi serta lebih rinci menyajikan hasil dari penelitian yang dilakukan. 


\section{REFERENSI}

Ardhian, D. (2011). Konflik Internal Organisasi Nir laba.

Creswell, J. W. (1994). Research Design Qualitative And Quantitative Approaches. London: Sage Publications.

Goulding, C. (1998). Grounded Theory: The Missing Methodology On The Interpretivist Agenda Qualitative Research. Knowledge Creation Diffusion Utilization, 1.

Hopwood, A. G. (1987). The archeology of accounting systems. Accounting, Organizations and Society. https://doi.org/10.1016/0361-3682(87)90038-9

Ives, M., Johnson, L., Razek, J. R., \& Hosch, G. A. (2004). Introduction to Governmental and Not-for-Profit Accounting (Six Ed. Pe). Prentice Hall.

Keraf, A. S. (2010). Etika Lingkungan Hidup.

Patton, J. M. (1992). Accountability and Govermental financial Reporting. Financial, Accountability, and Management, 8(3), 180.

Rahyuda, K. (2016). Metode Penelitian Bisnis. Denpasar: Udayana University Press.

Standbury, W. T. (2003). Accountability To Citizens In The Westnnster Model Of Government : More Myth Than Reality. Canada: Fraser Institute Digital Publication.

Tetlock, P. E., \& Kim, J. I. (1987). Accountability and Judgment Processes in a Personality prediction Task. Journal of Personality and Social Psychology, 52.

Visser, W., Matten, D., Pohl, M., \& Tolhurst, N. (2010). A To Z Corporate Social Responsibility. An ICCA Publication.

Wirajaya, I. G. A. (2014). Studi Etnografi Tentang Akuntabilitas Organisasi Desa Adat Kuta Bali. Universitas Brawijaya. 